\title{
Assessing the Difference in Time to Increase Hemoglobin Levels at 1 hour, 6 hours, and 12 hours after Blood Transfusion in Thalassemia Patients at the Regional General Hospital Dr. Zainoel Abidin Banda Aceh
}

\author{
Riny Fasli ${ }^{1}$, Heru Noviat Herdata ${ }^{2}$, Dora Darussalam $^{3}$, Bakhtiar $^{4}$, Sulaiman $_{\text {Yusuf }}{ }^{5}$, \\ Syafruddin Haris ${ }^{6}$, Rusdi Andid ${ }^{7}$, Mulya Safri ${ }^{8}$, Eka Destianti Edward ${ }^{9}$ \\ 1,2,3,4,5,6,7,8,9 Department of Pediatrics, Faculty of Medicine, Universitas Syiah Kuala / RSUD Dr. Zainoel \\ Abidin, Banda Aceh, Indonesia
}

\begin{abstract}
Thalassemia is a congenital blood disorder characterized by reduced production of one or more globin chains. Thalassemia patients lack healthy hemoglobin which the body needs to be properly oxygenated. Blood transfusion is the main treatment for thalassemia patients. Checking hemoglobin levels after transfusion is a common test, but until now there is no definite uniformity of time to carry out these tests, so it will be detrimental to the patient and increase the length of the patient in the hospital. Assessing the difference in time to increase in hemoglobin levels at 1 hour, 6 hours, and 12 hours after blood transfusion in thalassemia patients. This research is an observational analytic study with cross sectional design. This study was conducted by examining the hemoglobin levels of thalassemia patients after 1 hour, 6 hours, and 12 hours after transfusion in thalassemia patients aged 1-18 years with a total sample of 40 people. The statistical analysis used was paired t test. The results showed that 20 men and 20 women and Most were in the age group 10-13 (35\%), with an average $\mathrm{Hb}$ level at admission of $7.38 \mathrm{~g} / \mathrm{dL}(95 \% \mathrm{CI})$. At 1 hour post-transfusion, the patient's mean $\mathrm{Hb}$ level increased by $8.97 \mathrm{~g} / \mathrm{dL}(8,59-9,35 \mathrm{~g} / \mathrm{dL})$, at 6 hours post transfusion, $8.95 \mathrm{~g} / d L(8,57-9,32 \mathrm{~g} / \mathrm{dL})$, at 12 hours post transfusion increased by $9.60 \mathrm{~g} /$ $d L$ (9,17-10,03 $g / d L)$. Significant increase in Hb levels occurred at 1 hour and 12 hours after blood transfusion.
\end{abstract}

Keywords: thalassemia; hemoglobin level; post transfusion; time of examination

\section{Introduction}

Thalassemia is a congenital blood disorder characterized by reduced production of one or more globin chains. Hemoglobin $(\mathrm{Hb})$ consists of alpha and beta chains, in patients with thalassemia an error in $\mathrm{Hb}$ is generated. In patients with thalassemia there is a deficiency of healthy $\mathrm{Hb}$ which the body needs to become well oxygenated. (Elizalde, JL. 1997; Wahidiyat, PA. 2018; Hamizah, L. 2017). Thalassemia is the single most common gene disorder found. This disease was first discovered by Thomas B. Cooley in 1925 in a number of children with symptoms of anemia and an enlarged spleen after 1 year.2 The prevalence of thalassemia carrier in Indonesia is around 3\%-8\%. If the percentage of thalassemia reaches $5 \%$, with a birth rate of 23 per 1,000 of the 240 million populations, it is estimated that around 3,000 babies with thalassemia are born in Indonesia each year.

Blood transfusion in thalassemia is the main treatment that has been implemented worldwide. This action is carried out regularly for life to maintain the quality of life of the person who has it. This red blood cell transfusion was given for the first time according to the $\mathrm{Hb}$ level. The goal of transfusion is to maintain the pre-transfusion $\mathrm{Hb}$ level of $9.5 \mathrm{~g} / \mathrm{dL}$ to $10.5 \mathrm{~g} \mathrm{/} \mathrm{dL}$. The transfusion interval can vary from patient to patient, usually at 4 -week 
intervals because the $\mathrm{Hb}$ reduction rate is $1 \mathrm{~g} / \mathrm{dL} /$ week. (Wahidiyat, PA. 2018; Hamizah, L. 2017; Nikmah, M. 2018; Cappellini, MD. 2014)

Packed Red Cell (PRC) or red blood cells are the components of the blood most often used in transfusions, especially in thalassemia patients. The goal of PRC therapy is primarily to improve tissue oxygenation and increase the oxygen-carrying capacity of blood. Tissue oxygen demand is determined by $\mathrm{Hb}$ levels and haematocrit (Agarwal, 2016). In pediatric patients who require routine transfusions, transfusions are given at pre-transfusion $\mathrm{Hb}$ levels of 9.0-10.0 g / dL, to maintain growth and development close to growth and development in normal children.

Examination of hemoglobin levels after blood transfusion is very important because it is associated with further management. However, until now there are no definite guidelines related to the timing of this $\mathrm{Hb}$ examination. So sometimes it is detrimental to the patient. Even in Dr. Hospital Zainoel Abidin himself until now there are no fixed guidelines regarding the timing of $\mathrm{Hb}$ examination after blood transfusion. For patients with short treatment (one day care) such as thalassemia or chemotherapy, or in patients who need immediate surgery, the timing of blood sampling for checking $\mathrm{Hb}$ levels is crucial for further management.

A study conducted by Wiesen et al (1994) concluded that the measurement of hemoglobin levels could be taken 15 minutes after a PRC transfusion and the results showed a stable increase in $\mathrm{Hb}$ values. Research by Elizalde, et all (1997) reported that examination of $\mathrm{Hb}$ levels between 15 minutes and 24 hours after transfusion was very good, only about $6 \%$ of patients showed a significant difference to this measurement. Thus the experts can provide a rapid decision and follow-up management of the results of the transfusion, especially in patients with a risk of recurrent bleeding.

\section{Research Methods}

The research design was analytic observational with a cross sectional study. The sample in this study was taken by consecutive sampling, which is a non-probability sampling technique, obtained 40 samples that met the inclusion criteria, namely thalassemia patients aged 1-18 years, with $\mathrm{Hb}$ at admission $<10 \mathrm{~g} / \mathrm{dl}$, not with active bleeding and receiving transfusions. 1 bag of blood in 24 hours in the pediatric ward Dr. General Hospital. Zainoel Abidin Banda Aceh for the period of August-October 2019 and patients with transfusions of more than 1 bag in 24 hours, bleeding disorders, signs of infection or sepsis, thalassemia patients with comorbidities (impaired liver function, kidney disease, heart disease, malnutrition), died during the study and did not sign the informed consent was excluded from the study. The independent variable in this study was the time to check $\mathrm{Hb}$ levels (1 hour, 6 hours, 12 hours after blood transfusion), while the dependent variable was the $\mathrm{Hb}$ level. Analysis of the data in this study using paired $t$ test, the data is significant if $p<0.05$. Data processing was performed with a computer program (SPSS 22.0 for windows).

Examination of $\mathrm{Hb}$ levels in this study was carried out using a Hemometer $(\mathrm{Hb}$ Test meter brand Family Dr), by taking capillary blood at the fingertips of patients who had previously been given topical local anesthesia and then cleaned using alcohol swabs, then blood was drawn using a micropipette of $7 \mu \mathrm{L}$ and put into the $\mathrm{Hb}$ meter stick, wait for about 5 seconds and the result will appear on the $\mathrm{Hb}$ meter screen. The pyriapism is the immediate return of blood flow to the cavernous corpora which is achieved both medically and operatively (Gani, 2020). 
The examination was carried out four times, namely at the time of initial admission, then after 1 hour, 6 hours, and 12 hours after the blood transfusion. This research has obtained ethical feasibility from Ethics Committee of the University School of Medicine Syiah Kuala Banda Aceh with registration number 154 / EA / FK-RSUDZA / 2019., on 12 July 2019.

\section{Discussion}

The basic characteristics of thalassemia patients in dr. Zainoel Abidin Banda Aceh, who was the sample in this study, was seen from the variables of gender, age group, regional origin and the time of their routine blood transfusion. An overview of the basic characteristics of the sample of study patients is shown in Table 1.

Table 1. Basic Characteristics of the Study Sample

\begin{tabular}{lc}
\hline Variable & $\mathbf{N}(\mathbf{\%})$ \\
\hline Gender : & $20(50.0)$ \\
Man & $20(50.0)$ \\
Women & \\
Age group : & $4(10.0)$ \\
<5 years & $12(30.0)$ \\
5 - 9 years & $19(47.5)$ \\
10 - 14 years & $5(12.5)$ \\
$\geq 15$ years & \\
Origin : & $12(30.0)$ \\
Pidie & $6(15.0)$ \\
West Aceh & $6(15.0)$ \\
North Aceh & $6(15.0)$ \\
Aceh Besar & $4(10.0)$ \\
Aceh Jaya & $2(5.0)$ \\
Bireuen & $2(5.0)$ \\
Sabang & $1(2.5)$ \\
Pidie Jaya & $1(2.5)$ \\
Southwest Aceh & \\
Transfusion Time: & $4(10.0)$ \\
Every 2-3 weeks & $6(15.0)$ \\
Every 3 weeks & $30(75.0)$ \\
Every 3-4 weeks &
\end{tabular}

Overview of the patient's $\mathrm{Hb}$ level thalassemia in RSUD dr. Zainoel Abidin Banda Aceh at admission, 1 hour post transfusion, 6 hours post transfusion and 12 hours post transfusion are shown in Table 2.

Table 2. An Overview of the $\mathrm{Hb}$ Levels of Thalassemia Patients

\begin{tabular}{lcccc}
\hline \multicolumn{1}{c}{ Hb levels } & Min & Maximum & Median & Mean (95\% CI) \\
\hline When Entering & 5.60 & 9,10 & 7.35 & $7.38(7,13-7,64)$ \\
1 hour post & & 11.80 & & \\
transfusion & 7.30 & & 8.75 & $8.97(8.59-9.35)$
\end{tabular}


6 hours post

transfusion

6.60

12 hours post

transfusion
11.10

9.05

$8.95(8,57-9.32)$

12.00

Table 2 presents descriptive statistics of $\mathrm{Hb}$ levels in the form of minimum, maximum, median, and average values and 95\% confidence intervals (95\% CI). Based on Table 2, it is known that the average value of $\mathrm{Hb}$ levels at the time of entry is $7.38 \mathrm{~g} / \mathrm{dL}$ (7.13-7.64 $\mathrm{g} / \mathrm{dL}$ ). The median $\mathrm{Hb}$ level at admission showed that $50 \%$ of patients or a total of 20 people had $\mathrm{Hb}$ levels below $7.35 \mathrm{~g} / \mathrm{dL}$ and the other $50 \%$ had $\mathrm{Hb}$ levels above $7.35 \mathrm{~g} / \mathrm{dL}$. At 1 hour post-transfusion, the patient's mean $\mathrm{Hb}$ level increased to $8.97 \mathrm{~g} / \mathrm{dL}$ (8.59-9.35 g / dL) with the median value also increasing to $8.75 \mathrm{~g} / \mathrm{dL}$. Furthermore, at 6 hours post transfusion, the average $\mathrm{Hb}$ level decreased to $8.95 \mathrm{~g} / \mathrm{dL}(8.57-9.32 \mathrm{~g} / \mathrm{dL})$. However, the median value at 6 hours post transfusion increased to $9.05 \mathrm{~g} / \mathrm{dL}$. The average $\mathrm{Hb}$ level again increased at 12 hours after transfusion to $9.60 \mathrm{~g} / \mathrm{dL}(9.17-10.03 \mathrm{~g}$ / dL). At 12 hours post-transfusion, half of the patients had an $\mathrm{Hb}$ level greater than $9.50 \mathrm{~g}$ / dL.

Table 3, provides information about the calculation of the increase or decrease in $\mathrm{Hb}$ levels at 1, 6 and 12 hours post-transfusion. The assessment is calculated based on the $\mathrm{Hb}$ level at admission, so that data on changes in $\mathrm{Hb}$ levels can be analyzed to determine when the significant increase in $\mathrm{Hb}$ levels occurred after blood transfusions in patients.thalassemia.

Table 3. An Overview of Changes in Hemoglobin Levels in Thalassemia Patients at 1,6 and 12 Hours Post Transfusion

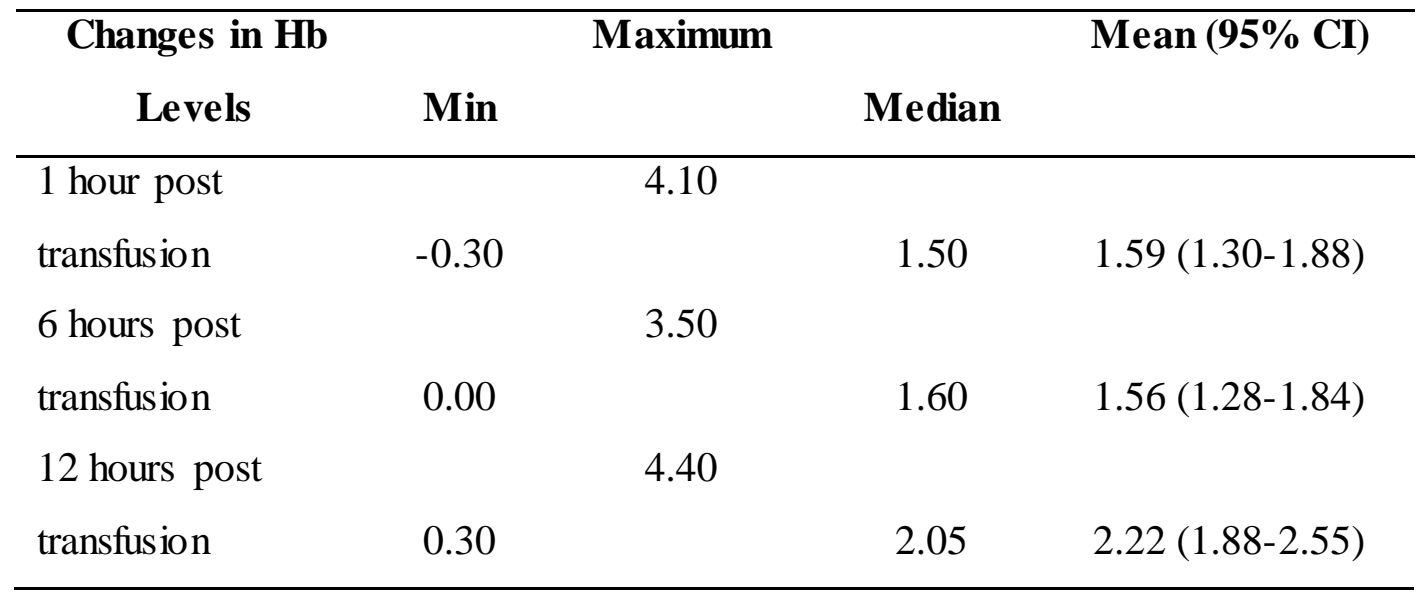

Table 3 shows that there was a change in $\mathrm{Hb}$ levels at 1 hour after transfusion compared to the time of admission with an average increase of $1.59 \mathrm{~g} / \mathrm{dL}(1.30-1.88 \mathrm{~g} /$ $\mathrm{dL}$ ). In addition, it is known that $50 \%$ of patients have an increase in Hb level above $1.50 \mathrm{~g}$ / dL which is reflected in the median value. An interesting thing happened at 6 hours post transfusion, where the mean $\mathrm{Hb}$ level in the patient decreased to $1.56 \mathrm{~g} / \mathrm{dL}(1.28-1.84 \mathrm{~g} /$ dL) when compared with the change at 1 hour post. transfusion. The median $\mathrm{Hb}$ level at 6 hours post transfusion was $1.60 \mathrm{~g} / \mathrm{dL}$. Hb levels increased significantly at 12 hours post transfusion with an average increase in $\mathrm{Hb}$ levels of $2.22 \mathrm{~g} / \mathrm{dL}(1.88-2.55 \mathrm{~g} / \mathrm{dL})$ from the start of admission. 
Although descriptively there are differences in the increase in Hb levels at 1, 6 and 12 hours post transfusion, further analysis is needed to determine the time of significant increase in $\mathrm{Hb}$ levels in thalassemia patients. The statistical method that can be used to prove this is the Paired sample $t$ test analysis or the non-parametric Wilcoxon test. Both statistical tests are used because the data in this study are paired data, namely data that comes from the same sample but is measured several times at different times.

In this study, the data normality test was performed using the Shapiro-Wilk test. The null hypothesis (Ho) in the normality test states that the data is clearh is normally distributed. Table 4 presents the results of testing the assumption for normality of data on changes in $\mathrm{Hb}$ levels at 1, 6 and 12 hours post-transfusion using the Shapiro-Wilk test.

Table 4. Testing the Assumption for Normality of Data on Changes in Hb Levels at 1, 6 and 12 Hours Post Transfusion

\begin{tabular}{lccc}
\hline \multicolumn{1}{c}{ Changes in Hb Levels } & Statistics & p-value & Decision \\
\hline 1 hour post transfusion & 0.958 & 0.148 & H0 is accepted \\
6 hours post transfusion & 0.981 & 0.734 & H0 is accepted \\
12 hours post transfusion & 0.973 & 0.445 & H0 is accepted \\
\hline
\end{tabular}

Table 4 shows that the data on changes in $\mathrm{Hb}$ levels of thalassemia patients at 1,6 and 12 hours post transfusion have been distributed normally as indicated by the p-value of testing $>0.05$. So that the analysis of changes in $\mathrm{Hb}$ levels of thalassemia patients at 1,6 and 12 hours post transfusion was carried out using the Paired sample $t$ test method.

There are three data analyzes used to determine the time of the significant increase in $\mathrm{Hb}$ levels in thalassemia patients. The first analysis was to compare changes in $\mathrm{Hb}$ levels at 1 and 6 hours post transfusion. The second analysis was a comparison of changes in $\mathrm{Hb}$ levels at 1 and 12 hours post transfusion. The third analysis was a comparison of changes in $\mathrm{Hb}$ levels at 6 and 12 hours post transfusion. The results of the comparison analysis of $\mathrm{Hb}$ levels for the three times are shown in Table 5.

Table 5. Results of Comparative Analys is of Changes in Hemoglobin Levels in Thalassemia Patients

\begin{tabular}{ccccc}
\hline Comparison & $\begin{array}{c}\text { Average Value } \\
\text { of the } \\
\text { Difference }\end{array}$ & $\boldsymbol{t}$ & $\boldsymbol{p}$-value & Decision \\
\hline Data 1 - Data 2 & 0.025 & 0.163 & 0.871 & H0 is accepted \\
Data 1 - Data 3 & $-0,630$ & $-4,170$ & $<0.001$ & H0 is rejected \\
Data 2 - Data 3 & -0.655 & $-5,474$ & $<0.001$ & H0 is rejected \\
\hline
\end{tabular}

Information:

Data 1:Changes in $\mathrm{Hb}$ level 1 hour post transfusion

Data 2:Changes in $\mathrm{Hb}$ levels 6 hours post transfusion

Data 3:Changes in $\mathrm{Hb}$ levels 12 hours post transfusion 
Table 5 presents some important statistics in the Paired sample $t$ test, namely the average value of the data differences, the t-test statistic and the p-value of the test. Based on Table 5, it is known that in the first analysis (comparison of data on changes in $\mathrm{Hb}$ levels at 1 hour and 6 hours after transfusion), the average difference in the value of changes in $\mathrm{Hb}$ levels is 0.025 . The difference in positive values indicated that the change in $\mathrm{Hb}$ levels at 1 hour post transfusion was greater than the change in $\mathrm{Hb}$ levels at 6 hours post transfusion. Whereas in the second and third analyzes, the average difference in $\mathrm{Hb}$ levels was negative, indicating that the change in $\mathrm{Hb}$ levels at 12 hours was greater than the changes in $\mathrm{Hb}$ levels at 1 and 6 hours post transfusion.

The mean value of changes in $\mathrm{Hb}$ levels at 1 hour post transfusion did not differ much from the mean changes in $\mathrm{Hb}$ levels at 6 hours post transfusion. Whereas in the second analysis (comparison of changes in $\mathrm{Hb}$ levels at 1 hour and 12 hours after transfusion) and third (comparison of changes in $\mathrm{Hb}$ levels at 6 hours and 12 hours after transfusion), the null hypothesis was rejected because the p-value of the test was $<0.05$. This shows that the mean difference in changes in $\mathrm{Hb}$ levels at 1 and 12 hours posttransfusion and at 6 and 12 hours post-transfusion is not zero. In other words, there were significant differences in changes in $\mathrm{Hb}$ levels measured at 1 and 12 hours post transfusion and at 6 and 12 hours post transfusion. Thus, it can be concluded that the $\mathrm{Hb}$ level in thalassemia patients at dr. Zainoel Abidin Banda Aceh experienced a significant increase at 12 hours post transfusion. For the record, although the descriptive statistical value in Table 3 shows a decrease in $\mathrm{Hb}$ levels at 6 hours post transfusion, the Paired sample $\mathrm{t}$ test proves that the decrease in $\mathrm{Hb}$ levels at 6 hours post transfusion is not statistically significant.

Thalassemia is a blood disorder that is inherited due to mutations in the synthesis of beta-globin chains characterized by decreased hemoglobin, decreased erythrocyte production and anemia. The main treatment for this condition is regular red blood cell transfusion and iron chelation therapy. (Nikmah, M. 2018; KMKRI. 2018; Tari, K. 2018; Lal, A. 2018). The main indication for transfusion is if the hemoglobin level is less than 7 $\mathrm{g} / \mathrm{dl}$, while other indications are when the hemoglobin value is more than $7 . \mathrm{g} / \mathrm{dl}$ accompanied by clinical features such as abnormal facial changes, impaired body development, para-spinal mass, severe bone changes and enlarged liver and spleen. (Hamizah, L. 2017; Lal, A. 2018; Wahidiyat, PA. 2018).

$\mathrm{Hb}$ levels of children who will receive transfusion therapy also vary widely. Generally, $\mathrm{Hb}$ levels below $7 \mathrm{~g} / \mathrm{dl}$ have to be transfused, but sometimes there are other factors such as the appearance of hypoxic symptoms requiring transfusion even though $\mathrm{Hb}>7 \mathrm{~g} / \mathrm{dl} .6,12,13 \mathrm{Hb}$ levels before transfusion in patients in this study varied, ranging from $5.6 \mathrm{~g} / \mathrm{dl}$ to $9.1 \mathrm{~g} / \mathrm{dl}$. The $\mathrm{Hb}$ level before transfusion in most patients ranges from 6 $\mathrm{g} / \mathrm{dl}$ to $7 \mathrm{~g} / \mathrm{dl}$. The same result was also obtained by Ermaya, et al. 14, where the average thalassemia patient who would receive a transfusion had an $\mathrm{Hb}$ level> $7 \mathrm{~g} / \mathrm{dl}$. Isworo, et al15 also obtained the same results, namely the average $\mathrm{Hb}$ level before transfusion was $7.9 \mathrm{~g} / \mathrm{dl}$. However, different things were found by Andriastuti, et all6, in their research at Dr. Cipto Mangunkusumo in 2006-2009 concluded that the mean pre-transfusion $\mathrm{Hb}$ level was $6.2 \mathrm{~g} / \mathrm{dl}$. From these studies it can be seen that the $\mathrm{Hb}$ level before transfusion varies, but there may be other clinical conditions that cause a child to receive a transfusion.

In this study, after receiving a PRC transfusion as needed, each patient was tested for $\mathrm{Hb}$ levels 1 hour, 6 hours and 12 hours after the transfusion. On examination 1 hour after transfusion, the mean $\mathrm{Hb}$ level increased by $1.59 \mathrm{~g} \mathrm{/} \mathrm{dl}$. Six hours later, another examination was carried out, but the average $\mathrm{Hb}$ level decreased $(1.56 \mathrm{~g} / \mathrm{dl})$ compared to the previous examination. After 12 hours of receiving a transfusion, the $\mathrm{Hb}$ level increased 
by an average of $2.2 \mathrm{~g} / \mathrm{dl}$, so it can be concluded that the best time to check the $\mathrm{Hb}$ level is 12 hours after the transfusion.

Research conducted by Elizalde, et all calculated the increase in $\mathrm{Hb}$ and hematocrit at 15 minutes, 30 minutes, 60 minutes, 120 minutes, and 24 hours post transfusion. From this study it was agreed that 15 minutes and 24 hours after transfusion were the best times for $\mathrm{Hb}$ and hematocrit examination. Research conducted by Karndumri, et al (2020) on 60 patients divided into three groups of examination time, namely 1 hour, 4 hours, and 24 hours concluded that the $\mathrm{Hb}$ level examination one hour after transfusion had an increase of $1.21 \mathrm{~g} / \mathrm{dl}$, in the group that examined four hours after transfusion there was an increase in $\mathrm{Hb}$ levels by $1.19 \mathrm{~g} / \mathrm{dl}$, and in the group examined 24 hours after transfusion there was an increase of $0.95 \mathrm{~g} / \mathrm{dl}$. From this study it was concluded that the increase in $\mathrm{Hb}$ levels did not experience a significant difference each time.

A similar study was conducted by Glatstein et al (2005) but this study assessed an increase in hematocrit after 15 minutes and 6 hours post transfusion. In this study, it was stated that the increase in hematocrit had occurred immediately after the completion of the transfusion or at 15 minutes post-transfusion and the increase was the same as 6 hours after transfusion, so that with this assessment it could be decided that after immediate transfusion, it could be ascertained whether or not additional transfusion was necessary.

Another study conducted by Hoque, et al (2015), involved 100 patients in Dhaka who examined their hemoglobin levels before transfusion, 6 hours and 24 hours post transfusion. From this study, it was found that an increase in $\mathrm{Hb}$ levels at 6 hours after transfusion was $0.39 \mathrm{mg} / \mathrm{dl}$ and $1.14 \mathrm{mg} / \mathrm{dl}$ an increase in $\mathrm{Hb}$ at 24 hours post transfusion. This study concluded that the increase in $\mathrm{Hb}$ level at 6 hours post transfusion was not significant, but the best increase in $\mathrm{Hb}$ occurred at 24 hours after transfusion. The difference in the increase in $\mathrm{Hb}$ levels at 6 hours and 24 hours after transfusion was very significant and statistically significant. In line with the study of Linda, et al (2018), who examined $\mathrm{Hb}$ levels at 6-12 hours post-transfusion and 12-24 hours post-transfusion. There was no statistically significant difference in the average increase in $\mathrm{Hb}$ levels at the two times of the examination.

In this study, it was found that an increase in $\mathrm{Hb}$ levels had occurred 1 hour after the transfusion. The difference in $\mathrm{Hb}$ levels at 1 hour and 6 hours post transfusion was not significant and a significant increase occurred at 12 hours post transfusion. A similar study was conducted by Audu, et al. (Audu, LI. 2015) which assessed the increase in neonatal hemoglobin levels (Elizalde, JL. 1997; Cappellini, MD. 2014. Lal, A. 2018) at 24 and 48 hours after red blood cell transfusion. This study concluded that the increase in $\mathrm{Hb}$ levels was the same at 1 hour and 6 hours post transfusion, a significant increase at 12 hours post transfusion. $\mathrm{Hb}$ levels at 12 hours, 24 hours, and 48 hours post transfusion were the same. From this study, it was found that the increase in $\mathrm{Hb}$ occurred in a period of 12 hours after transfusion, so it is advisable to check $\mathrm{Hb}$ levels at this time. Similar results obtained by Siska (2019) in her research at RSUD Dr.

Another study conducted by Wiesen et al9 assessed $\mathrm{Hb}$ concentration at 15 minutes, 1 hour, 2 hours, and 24 hours post transfusion. This study concluded that the increase in $\mathrm{Hb}$ levels had occurred at 15 minutes post transfusion. $\mathrm{Hb}$ measurements carried out 15 minutes post transfusion reflected a stable value. Measuring this time is very useful in reducing outpatient waiting times and reducing the need for reexamination times of 24 to 48 hours. Another study conducted by Raja et al (Raja, A. 2020) on 80 people with thalassemia who received PRC transfusions found that there was an increase in $\mathrm{Hb}$ levels by 3-3.26 g / dl on examination one hour after transfusion. However, this study did not check $\mathrm{Hb}$ levels at any other time after the transfusion. 
The theory that is widely used today is that there is an increase in the Hb level of $1 \mathrm{~g}$ / dl per transfusion of one red blood cell unit. However, the stability of $\mathrm{Hb}$ levels was only reached 24 hours after the transfusion. $\mathrm{Hb}$ concentration at 24 hours post transfusion has increased by $110 \%$ from the value of the examination immediately after transfusion (Wiesen, AR, 1994; Shander, A. 2013) of all the studies that have been presented have different conclusions. This is due to the criteria of subjects with different backgrounds of causes of anemia. However, it can be seen that $\mathrm{Hb}$ levels begin to increase in the first 1 hour after transfusion and on average give the best results of increases in Hb levels 12-24 hours after transfusion.

The literature or previous studies discussing the best time to check the increase in hemoglobin concentration after blood transfusion in the last five years is very limited and there are no specific guidelines regarding this. So it is deemed necessary to carry out this research as a reference for further research and it is hoped that it can become a guideline for the institution itself.

\section{Conclusion}

Examination of $\mathrm{Hb}$ levels in the first 1 hour after transfusion has shown a significant increase so that after direct transfusion, it can be ascertained whether or not additional transfusions are needed and is useful in reducing the waiting time for outpatients or patients who require immediate action and shortening the length of stay of patients in hospital. There was a difference in the average $\mathrm{Hb}$ level at 1 hour, 6 and 12 hours post transfusion. A significant increase in hemoglobin occurred at 12 hours post transfusion and this already reflected the expected $\mathrm{Hb}$ level. In emergency conditions that require a decision for further management, post-transfusion $\mathrm{Hb}$ level checks can be done 1 hour after the transfusion is complete.

\section{References}

Agarwal, Anurag K, Paul, Rai, Shannon K. Unique aspects of red blood cell transfusion in pediatric patients. Int J Clin Transfus Med. 2016;4:43-54.

Andriastuti M, Sari TT, Wahidiyat P, Putriasih S. Kebutuhan Transfusi Darah PascaSplenektomi pada Thalassemia Mayor. Sari Pediatr. 2011;13:244-9.

Audu LI, Otuneye AT, Mairami AB, Mselia LJ, Nwatah V. Posttransfusion Haematocrit Equilibration: Timing Posttransfusion Haematocrit Check in Neonates at the National Hospital, Abuja, Nigeria. Int J Pediatr. 2015;1-5.

Cappellini MD, Cohen A, Porter J, Taher A, Vibrakasit V. Guidelines For The Management Of Transfusion Dependent. Edisi 3. Nicosia, Cyprus: Thalassemia International Federation; 2014; h. 14-26

DeBaun MR, Jones, Melissa JF, Vichinsky E. Thalassemia syndromes. Dalam: Robert M. Kliegman, editor. Nelson Textbook of Pediatrics. Edisi 20. Philadelphia; 2016. h. 2349-52.

Elizalde JL, Clemente J, Martin JL, Panes J, Aragon B, Mas A, dkk. Early changes in hemoglobin and hematocrit levels after packed red cell transfusion in patients with acute anemia. Transfusion. 1997;37:573-6.

Ermaya YS, Hilmanto D, Reniarti L. Hubungan Kadar Hemoglobin Sebelum Transfusi dan Zat Pengikat Besi dengan Kecepatan Pertumbuhan Penderita Thalassemia Mayor. 2007;57;380-4. 
Gani, A., and Jailani, M. (2020). Priapism in Patients Chronic Myeloid Leukemia. Budapest International Research in Exact Sciences (BirEx) Journal Vol 2 (4): 443 451.

Glatstein M, Oron T, Barak M, Mimouni FB, Dollberg S. Posttransfusion equilibration of hematocrit in hemodynamically stable neonates. Pediatr Crit Care Med. 2005;6:7078.

Hamizah L, Susanah S, Rakhmilla LE. Clinical Manifestations Of Children With Thalassemia Major: Clinical Course One Year Later. Asian J Biol Med Sci. 2017;3:h.1-11.

Hoque MM, Adnan SD, Karim S, Mamun MA Al, Nandy S, Faruki M Al, dkk. Equilibration and Increase of Hemoglobin Concentration after One Unit Whole Blood Transfusion among Patients Not Actively Bleeding. J Dhaka Med Coll. 2015;23:161-6.

Isworo A, Setiowati D, Taufik A. Kadar hemoglobin, status gizi, pola konsumsi makanan dan kualitas hidup pasien thalassemia. J Kep Soedirman. 2012;7:183-9.

Karndumri K, Tantiworawit A, Hantrakool S, Fanhchaksai K. Transfusion and Apheresis Science - Comparison of hemoglobin and hematocrit levels at 1, 4 and $24 \mathrm{~h}$ after red blood cell transfusion. Transfus Apher Sci [Internet]. 2020;59-60. Diunduh dari: https://doi.org/10.1016/j.transci.2019.06.021. Diakses pada 14 juni 2020.

Keputusan Menteri Kesehatan Republik Indonesia. Nomor HK.01.07/Menkes/1/2018: Pedoman Nasional Pelayanan Kedokteran Tatalaksana Thalasemia. 2018;1-90.

Lal A, Wong TE, Andrews J, Balasa VV, Chung JH, Forester CM, dkk. Transfusion practices and complications in thalassemia. Transfusion. 2018;58:2826-35.

Linda R, Ninda D. Differences in changes of hemoglobin between 6-12 hours and 12-24 haours after transfusion. Maj Patol Klin Indones dan Lab Med. 2018;24:108-11.

Nikmah M, Mauliza. Kualitas Hidup Penderita Talasemia berdasarkan Instrumen Pediatric Quality of Life Inventory 4.0 Generic Core Scales di Ruang Rawat Anak Rumah Sakit Umum Cut Meutia Aceh Utara. Sari Pediatr. 2018;20:11-16.

New HJ, Berryman J, Bolton-maggs PHB, Chalmers EA, Davies T, Gottstein R, dkk. Guidelines on transfusion for fetuses, neonates and older children British Society for Haematology. Br Soc Heamotology. 2016;1-91.

Raja A, Jain A, Marwaha N, Trehan A. Transfusion and Apheresis Science - Comparison of efficacy of packed red blood cell transfusion based on its hemo globin content versus the standard transfusion practice in thalassemia major patients ( HEMOCON study ). Transfus Apher Sci [Internet]. 2020;1:1-6.. Diunduh dari: https://doi.org/10.1016/j.transci.2020.102736. Diakses pada 14 juni 2020.

Shander A, Gross I, Hill S, Javidroozi M, Sledge S. A new perspective on best transfusion practices. Blood Transfus. 2013;11:193-202.

Siska SP. Gambaran kadar hemoglobin sebelum dan sesudah transfusi darah pada pasien anemia di RSUD DR. M. Zein Painan (skripsi). Padang : Sekolah Tinggi Ilmu Kesehatan Perintis, 2019.

Tari K, Ardalan PV, Abbaszadehdibavar M, Atashi A, Jalili A, Gheidishahran M. Thalassemia an update: molecular basis, clinical features and treatment. Int $\mathbf{J}$ BioMed Public Health. 2018;1:48-58.

Wahidiyat PA, Permono B. Hemoglobinopati dan Talasemia. Dalam: Windiastuti E, Nency YM, Mulatsih S, Sudarmanto B, Ugrasena IDG, editor. Buku Ajar Hemato Onkologi Anak Edisi Revisi. 2018.h. 60-80.

Wahidiyat PA, Permono B. Hemoglobinopati dan Talasemia. Dalam: Windiastuti, E. Nency YM, Mulatsih S, Sudarmanto B, Urgasena IDG, editor. Buku Ajar Hemato 
Onkologi Anak. Edisi Revisi. Jakarta: Badan Penerbit Ikatan Dokter Anak Indonesia; 2018. h. 60-79.

Wiesen AR, Hospenthal DR, Byrd JC, Glass KL, Howard RS, Diehl LF. Equilibration of hemoglobin concentration after transfusion in medical inpatients not actively bleeding. Ann Intern Med. 1994;121:278-80. 